\title{
KONFLIK BERSENJATA DI SABAH DAN PENYELESAIANNYA DALAM HUKUM INTERNASIONAL
}

\author{
JAWAHIR THONTOWI \\ Dosen Fakultas Hukum Universitas Islam Indonesia, Jl. Tamansiswa No. 158 Yogyakarta, Telp. \\ (0274) 379178, Fax. (0274) 377043, Email: impress_jawahir@yahoo.com.
}

\begin{abstract}
ABSTRAK
Tulisan ini menunjukkan bahwa Sabah secara hukum diakui sebagai bagian dari wilayah kedaulatan Malaysia. Fakta tersebut tidak hanya ditemukan dalam sejarah dan dasar hukum, serta prinsip uti posidetis juris. Tetapi juga Perserikatan Bangsa-bangsa menguatkannya melalui penyelenggaraan referendum di Sabah dan Sarawak tahun 1963. Konflik bersenjata di Sabah tidak dapat dikategorikan dalam konflik internasional dan konflik non-internasional. Namun, Konvensi Jenewa 1949, Protokol Tambahan II 1977, dan Konvensi Internasional tentang Hak Asasi Manusia dapat diterapkan dalam peristiwa konflik bersenjata di Sabah. Adanya Kombatan, penggunaan senjata, dan korban jiwa, secara signifikan dapat diidentifikasi sebagai konflik bersenjata. Konsekuensi hukumnya, konflik bersenjata di Sabah dapat membuka peluang bagi beberapa pihak terlibat dimintai pertanggungjawaban hukum. Tidak hanya Pemerintah Malaysia yang dapat dibawa ke hadapan Mahkamah Internasional atas pelanggaran Konvensi Jenewa dan Hak Asasi Manusia. Tetapi juga, pihak pengikut Kesultanan Sulu dapat dibawa ke peradilan nasional atas tindakan pelanggaran keimigrasian, dan juga pelanggaran atas Undang-Undang Keamanan Nasional (Internal Security Act) sebagaimana halnya dengan UndangUndang Terorisme. Meskipun demikian, tidak menutup kemungkinan pihak Kesultanan Sulu dapat menuntut Pemerintahan Malaysia atas sengketa hak peralihan keuntungan bersifat keperdataan yang menjadi klaim dalam konflik bersenjata.
\end{abstract}

Kata kunci : Konflik bersenjata internasional, kedaulatan wilayah, pertanggungjawaban hukum.

\begin{abstract}
This articles reveals that Sabah is legally recognized as a part of Malaysian integrated territory. This fact is not only found due to historical and legal basis on uti posidetis juris principle, but also because the UNO confirmed it by conducting referendum in Sabah and Sarawak 1963. Eventhough arm conflict in Sabah is not categorized as international conflict, the Geneva Convention 1949, Protocol II 1977, and International Human Rights Convention can be applicable to examine the arm conflict in Sabah. The inclusion of combatants, weapon used, victims and causalities, have been contributed in significant to identify the arm conflict. As a result, this arm conflict in Sabah has open an opportunity for the involved parties, not only the Malaysian Government can be brought in International Court of Justice for the violent of Geneva Convention and Human Rights, but also the Sultan Sulu followers could also be brought into national court, for the imigration infringement, and ISA as well Terrorist Act. Nonetheless, there will be an opportunity for the Sultan Sulu to sue the government of Malaysia to claim the rights of private property.
\end{abstract}

Keyword: International Arm Conflict, Territorial integrity, Legal Responsibility. 


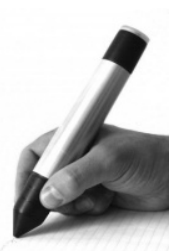

\section{PENDAHULUAN}

Pemerintah Malaysia cukup beralasan ketika menggunakan kekuatan militer, terhadap pengikut Sultan Sulu yang menyusup ke

Negara Bagian Sabah 2 Maret 2013. Tindakan kedaulatan Pemerintah Malaysia dapat dipandang sebagai tindakan kedaulatan karena membela diri (self defend rights) atas serangan pengikut-pengikut Sultan Sulu yang lengkap dengan persenjataannya memasuki wilayah Sabah. Karena itu, tidak mengherankan jika Pemerintah Malaysia terkesan tidak ragu untuk menghadang pasukan Sultan Sulu dengan kekuatan militer. Tujuh batalyon militer, sekitar 7000 kekuatan militer diturunkan ke Sabah sebagai upaya mempertahankan kedaulatan wilayah.

Tulisan ini bermaksud menjelaskan tentang isu-isu hukum sekitar wilayah kedaulatan negara dan implikasinya terhadap timbulnya konflik bersenjata dan penyelesaiannya secara hukum internasional. Hal ini timbul ketika Sultan Sulu, Jamaluddin Kiram III mengajukan klaim wilayah Sabah kepada Pemerintah Filipina sekitar tahun 1970-an. Klaim Sultan Sulu tersebut didasarkan pada ikatan sejarah, bahwa Sabah merupakan wilayah yang dihadiahkan Sultan Brunei kepada Sultan Sulu. Mengingat bantuan Sultan Sulu ketika Sultan Brunei dilanda kerusuhan sekitar abad ketujuhbelasan. 


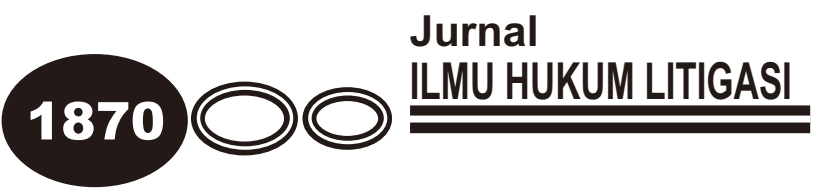

Namun, permohonan Sultan Sulu tersebut tidak didukung i'tikad baik Presiden Filipina. Bahkan sejak terbentuknya organisasi ASEAN, Pemerintah Filipina justru secara formal menyerahkan urusan Sabah menjadi bagian dari Malaysia. Situasi politik internal Filipina tersebut tidak terlepas dari fakta bahwa kelompok Muslim di Filipina Selatan menghendaki pemisahan menjadi negara sendiri.

Sikap abai Pemerintah Filipina membuat Kesultanan Sulu tampaknya sangat mengecewakan. Akumulasi kekecewaan tersebut diwujudkan melalui upaya penyusupan pengikut Sultan Sulu ke Sabah. Dalam suatu penyusupan sekitar bulan Februari 2013, dan sekitar tanggal 2 sampai dengan 5 Maret, pertikaian bersenjata tidak dapat dihindarkan. Konflik bersenjata tersebut berakibat tidak kurang dari tujuh puluh (70) orang tewas, termasuk 7 orang dari Polisi Diraja Malaysia, dan 76 orang ditahan di Malaysia. Meski benar telah terjadi konflik bersenjata di Sabah, isu-isu hukum yang timbul apakah konflik internasional atau konflik non-internasional menjadi persoalan menarik untuk dilakukan pengkajian.

Adapun dalam tulisan ini permasalahan yang akan dikaji sebagai berikut:

1. Bagaimana suatu wilayah menjadi wilayah kedaulatan utuh (territorial integrity) suatu negara? 
2. Apakah status dan kedudukan Sabah sebagai wilayah negara bagian Malaysia menurut hukum internasional?

3. Bagaimana konflik dan kekerasan terjadi antara Sultan Sulu dengan Pemerintah Malaysia di Sabah?

4. Bagaimana pertanggungjawaban hukum dapat dibebankan kepada pihak-pihak terlibat dalam konflik bersenjata menurut Geneva Convention 1949?

\section{METODE PENELITIAN}

Adapun metode pendekatan lebih ditekankan pada jenis penelitian normatif, yaitu ketentuan hukum internasional, perjanjian internasional, Piagam PBB 1945, dan Konvensi Jenewa 1949, termasuk Protokol Tambahan 1977. Sedangkan bahan hukum sekunder diambil dari berbagai literatur yang relevan, terutama terkait dengan penggunaan konsep dan teori yang dapat digunakan untuk menjelaskan persoalan konflik bersenjata (armed conflict).

Analisis yang digunakan dalam penelitian ini, selain lebih melihat pada fungsi norma hukum internasional, analisis peran atas negara dan juga Sultan, serta digunakan analisis historis yang terkait dengan dua kondisi hukum. Hukum antar waktu (inter-temporal law) yang melibatkan selain latar belakang keluarga 


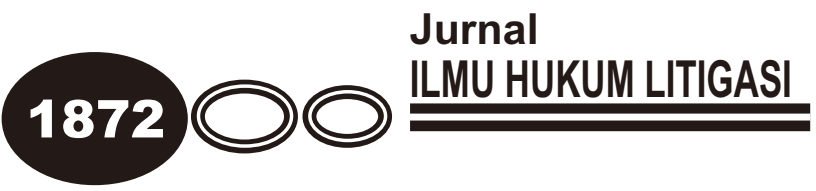

(Sultan Sulu), kekerabatan, dan juga agama yang memberikan dukungan atas motif lahirnya konflik bersenjata yang berada diluar tipologi hukum internasional. Kondisi tersebut menjadi sangat relevan untuk diteliti, dengan harapan terdapat informasi akademis terkait dengan konflik bersenjata di satu pihak Malaysia sebagai subyek hukum negara, dan dipihak lain Sultan Sulu, warga negara asing dari Filipina.

Argumentasi dalam tulisan dikedepankan bahwa kemerdekaan bagi suatu negara dari kekuatan negara-negara penjajah tidak secara otomatis memberikan jaminan kepastian hukum atas wilayah-wilayah yang diduduki. Tindakan unilateral penguasa tradisional, sultan atau raja-raja yang oleh pihak penjajah dijadikan landasan penentuan batas wilayah kedaulatannya, melalui konsep uti posidetis terbukti baru sebatas memberi jawaban atas isu hukum wilayah perbatasan secara umum. Karena itu, perselisihan antara negara-negara yang berakhir dengan konflik bersenjata terjadi bukan karena batas-batas wilayah lebih rinci belum disepakati, tetapi lebih disebabkan karena mobilitas penduduk di wilayah perbatasan amat rentan dengan konflik bersifat internasional. 


\section{HASIL PENELITIAN DAN ANALISIS}

\section{A. Wilayah Kedaulatan Negara-Negara}

Penentuan wilayah dan batas-batas negara sangat tergantung pada sejarah yang melatarinya. Penentuan wilayah secara sepihak atau unilateral act yakni suatu penentuan wilayah dan batas-batasnya berdasarkan prinsip-prinsip okupasi atau pendudukan. Hal ini terjadi ketika wilayah tersebut masih kosong, atau belum ada pemiliknya "terra nullius". Sedangkan, akresi suatu penyerahan wilayah secara damai oleh suatu negara ke negara lain. Penambahan wilayah terjadi sebagai akibat perubahan atau bencana alam atau akresi. Dan terakhir, suatu klaim atas wilayah didapat dengan cara perampasan atau penaklukan (conquest) dengan agresi militer. Model terakhir ini dipandang sebagai model pendudukan dengan peperangan yang menurut hukum internasional tidak dibenarkan (illegal) (O'Brian, John, 2001: 213). Hal ini terjadi sejak penerimaan Doctrin Stimson, Doctrin of Non Recognition, yaitu suatu wilayah yang dikuasai dengan menggunakan kekerasan tidak diakui.

Secara historis, negara-negara umumnya lahir dari bekas negara jajahan, dan model penentuan wilayah sepihak ini dikenal dengan istilah penentuan batas-batas wilayah didasarkan pada penguasaan atau pemilikan pemerintah jajahan sebelumnya, atau dikenal sebagai uti posidetis juris. 


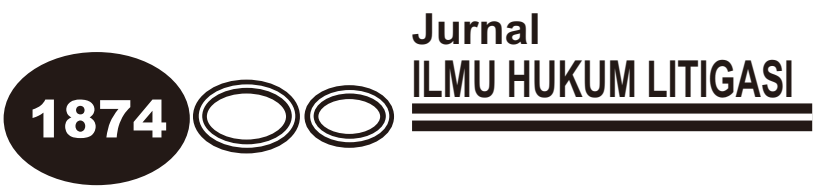

Berdasarkan perjanjian bilateral negara-negara penjajahnya, dan negara-negara pemberi disebut sebagai predecessor, dan negara-negara penerima disebut successor. Tentu saja, kedua konsep tersebut lebih sesuai digunakan bagi negara-negara yang lahir akibat adanya suksesi dalam konteks hukum internasional (Dixon dan McCorquodale, 2003).

Sedangkan dalam penentuan batas-batas wilayah negara masingmasing, yang antara lain: (1) allocation, adalah penentuan cakupan wilayah suatu negara yang ditetapkan berdasarkan ketentuan-ketentuan baik hukum internasional, maupun hukum nasional. Alokasi lebih merujuk kepada sebuah keputusan politik; (2) delimitation, adalah penetapan batas wilayah antara dua negara yang sebagian cakupan wilayahnya overlaping, atau melampaui batas wilayah negara lain; (3) demarcation atau penegasan batas wilayah suatu negara setelah ditetapkan oleh negara-negara yang berbatasan. Penegasan batas wilayah dapat dilakukan dengan cara memasang tanda-tanda batas di sepanjang batasan wilayah yang diperjanjikan; dan (4) join border committee, lebih dimaksudkan sebagai upaya administrasi atau manajemen pembangunan di wilayah perbatasan, yang pelaksanaannya dilakukan melalui kerjasama dengan pemerintah negara tetangga. Kerjasama pengelolaan wilayah perbatasan 
sangatlah besar, sehingga peran pemerintah daerah untuk terlibat secara aktif sangat diperlukan (Ludiro, Madu, et.al, 2010: 15-19).

Dalam kaitannya dengan wilayah Sabah, memang tidak luput dari kemungkinan wilayah over-lapping. Selain kesejarahan, Inggris pernah menjajah Pulau Borneo atau Kalimantan, yang tidak menjadi milik Malaysia dan tidak pula milik Indonesia. Sebab, Negara Brunei Darussalam pada tahun 1970-an merupakan contoh kasus yang tepat. Ketiga negara yang berdampingan menduduki Pulau Borneo tersebut, kini menjadi anggota organisasi internasional bernama ASEAN. Sampai saat ini, beberapa negara ASEAN masih menyimpan permasalahan batas wilayah adalah Indonesia Malaysia, baik darat dan lautan. Sebagaimana Thailand dengan Kamboja, utamanya terkait dengan posisi Candi Kuno Preah Vihear yang ada di wilayah kedua negara. Terakhir, masyarakat internasional di hebohkan dengan negara bagian Sabah Malaysia yang diklaim sebagai wilayah milik Kesultanan Sulu Filipina. Anehnya, ASEAN tidak terdengar merespon secara memadai dibandingkan dengan Sekjen PBB Ban Kim Moon (Harian Kompas, tanggal 16 Maret 2013). Dia menyerukan agar konflik dan kekerasan segera dihentikan dan konflik segera ditempuh penyelesaiannya dengan jalan damai demi 


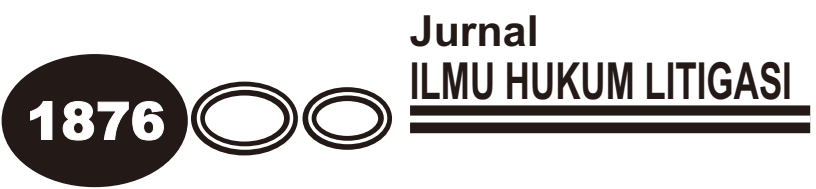

menghindari korban sesuai amanah dan tujuan PBB Pasal 1 ayat (3) (Harian Kompas, tanggal 16 Maret 2013).

Pasal 1 ayat (3) menyebutkan bahwa: mengembangkan hubungan persahabatan antar bangsa berdasarkan penghormatan terhadap prinsip persamaan hak dan penentuan nasib sendiri masyarakat, dan untuk mengambil tindakan yang tepat lainnya untuk memperkuat perdamaian universal (http://id.wikisource.org).

Lebih jauh, Malcolm Shaw, dari pengalaman penelitiannya terkait dengan penjajahan Eropa di Afrika, menyebutkan tiga metode perolehan wilayah kedaulatan negara :

(a) Pendudukan efektif dan konsep terra nullius. Suatu konsep tentang perolehan wilayah di dasarkan pada wilayah yang masih kosong atau belum ada pemiliknya, atau suatu persatuan wilayah secara damai (the peacefull acquisition) atas suatu kedaulatan wilayah, atau sebagaimana model cession atau succession. Terra nullius, sebagai suatu metode perolehan wilayah disebabkan tempat tersebut wilayahnya tidak ada penghuninya (uninhabitated areas) atau wilayah kosong yang ditinggalkan (abandoned territories) atau res delicta (Shaw, Malcolm, $1986: 33$ ). 
(b) Cession, model perolehan wilayah melalui suatu perjanjian, dimana pihak-pihak antara penjajah dengan orang-orang lokal, sebagai entitas sosial politik menyerahkan sebagian wilayah untuk menjadi suatu wilayah kedaulatan. Model ini dikeluarkan dengan metode terra nullius oleh karena kekuasaan Eropa sebagaimana terjadi di Afrika, dengan menggunakan penyelesaian secara damai. Hal ini didasarkan pada The General Act to The Berlin Conference of 1884. Esensinya adalah, Pasal 1 menegaskan bahwa prinsip kemerdekaan untuk perdagangan dan navigasi pelayaran, sebagaimana didasarkan pada wilayah perairan Kongo, hanya diberlakukan bagi wilayah-wilayah negara yang merdeka. Contoh cessie, yaitu Pantai Arab (arab bay) juga Libia ke Italia tahun 1880.

(c) Penaklukan (conquest), suatu cara peralihan suatu wilayah dari wilayah musuh dalam suatu keadaan sedang perang. Model penaklukan ini sangat penting dalam sejarah politik, mengingat operasi penaklukan merupakan cara yang lazim dipergunakan.

Perolehan wilayah melalui penaklukan (conquest) dan kekerasan, umumnya dipandang sebagai tindakan yang tidak sah. Suatu wilayah tidak dapat dipandang sebagai peralihan pemilikan, jika negara yang dipandang 


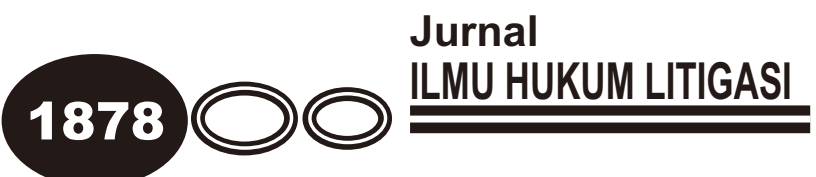

memenangkan peperangan belum mendeklarasikannya kepada negara-negara pihak. Menurut Hakim Yesuf dalam kasus The South West African Cases, ditegaskan bahwa hukum internasional tidak mengakui penaklukan dengan agresi militer sebagai sumber pemilikan suatu wilayah (Starke, J. G., : 166 dan Jawahir dan Pranoto, 2006). Dalam kondisi tertentu, praktek penaklukan dapat diterima sebagai pengecualian. Misalnya, suatu wilayah di Rhodesia Selatan bagian benua Afrika. Pemerintah kolonial Inggris telah mendeklarasikan kepada Portugis, bahwa Kerajaan Matabeleland pimpinan Lobengula sebagai kerajaan merdeka yang dijamin oleh suatu perjanjian kedua negara penjajah tahun 1893 (http://www.bulawayo1872.com). Begitu juga kasus Madagaskar di Afrika, penaklukannya didahului dengan perjanjian perlindungan (Shaw, Malcolm, 1986 : 46). Kondisi pengecualian tersebut berlaku sebelum lahirnya PBB 1945.

B. Sabah Negara Bagian Malaysia

Tidak banyak keraguan untuk menolak klaim Sultan Sulu atas Sabah sebagai wilayah kedaulatan Malaysia. Sejak September 1963, Malaysia mendeklarasikan kemerdekaannya dari penjajahan Inggris. Negara serikat (federal state) yang terdiri dari tiga belas negara bagian antara lain: Johor, 
Kedah, Kelantan, Melaka, Negeri Sembilan, Pahang, Perak, Perlis, Pulau $\begin{array}{llll}\text { Pinang, Sarawak, } & \text { Selangor, } & \text { dan } & \text { Trengganu }\end{array}$ (http://id.wikipedia.org/wiki/Daftar_). Salah satunya, Sabah sebagai negara bagian sah Malaysia.

Adapun model pemerintahannya bersifat ministerial, yang dipimpin oleh seorang Perdana Menteri yang didukung oleh Sultan Yang Dipertuan Agung. Di setiap negara bagian tersebut, Sultan masih memainkan peranan penting dalam memastikan Islam sebagai agama negara dan juga membantu terselenggaranya kesejahteraan rakyat. Ciri lain adalah sebagian besar negaranegara mantan jajahan Inggris, terikat oleh organisasi negara-negara persemakmuran (commonwealth states) dan bentuk negara dengan sifat pemerintahannya sama, seperti Australia, Kanada, India, Malaysia, dan Pakistan (http://en.wikipedia.org/wiki/Member_).

Negara-negara yang terikat sebagai anggota persemakmuran tersebut, secara historis memiliki karakter budaya dan politik, serta tingkat kemajuan hubungan internasional yang lebih terbuka. Mengingat bahasa Inggris merupakan bahasa nasional kedua yang digunakan sehari-hari. Misalnya, Malaysia mempergunakan bahasa Melayu sebagai bahasa nasional, tetapi bahasa Inggris jauh lebih digunakan sebagai bahasa resmi negara tersebut. 


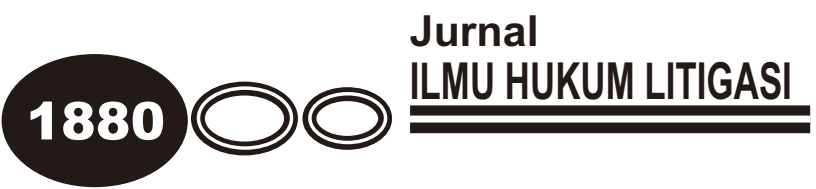

Ada beberapa alasan mengapa Sabah merupakan wilayah sah dari negara Malaysia. Pertama, legitimasi Sabah sebagai Negara Bagian Malaysia, terkait sejarah hukum kelanjutan administrasi kekuasaan Inggris. Secara hukum internasional, tidak terdapat celah yang melemahkan kepemilikan Sabah, dari kedaulatan utuh Malaysia. Dari teori suksesi, Sabah bagian dari wilayah kolonialisasi Inggris sebagai predecessor, yang mewarisi Malaysia sebagai negara successor. Sekiranya, Sabah diletakan pada teori uti posidetis, utamanya didasarkan dokumen perjanjian internasional, antara pemerintah kolonial Inggris dan Belanda, maka pemilikan Malaysia terhadap Sabah tampak secara hukum memiliki status yang pasti. Fakta sejarah tersebut dapat digunakan sebagai sumber hukum materiil dalam penentuan batas wilayah kedaulatan (Jawahir, Thontowi, 2012).

Kedua, kedudukan Malaysia sangat kuat dan legitimit ketika menentukan wilayah-wilayah kedaulatan negaranya. Negara Bagian Serawak dan Sabah dijadikan wilayah kedaulatan Malaysia tidak dilakukan secara sepihak (unilateral act). Akan tetapi, mengacu pada Pasal 1 ayat (3) Piagam PBB (http://id.wikisource.org/wiki/Piagam_), terkait dengan penentuan nasib sendiri (self determination) melalui prosedur referendum dibawah pengawasan 
PBB tahun 1963. PBB telah memutuskan bahwa negara bagian Serawak dan Sabah bergabung dengan Malaysia (Harian Kedaulatan Rakyat, tanggal 10 Maret 2013). Kondisi referendum tersebut, tentu agak mirip dengan proses masuknya Papua Barat tahun 1963 (http://www.gwu.edu), dalam proses penggabungannya (reimbursement), dan Timor Timur yang lepas (disemberment) dari Indonesia tahun 1999 juga berada dibawah pengawasan PBB (http://en.wikipedia.org/wiki/United_Nations).

Ketiga, Pemerintah Malaysia tampak semakin kuat dalam mempertahankan Sabah, sebagai wilayah kedaulatannya. Di satu pihak, Sabah tergolong wilayah kedaulatan yang utuh (a territorial integrity) Malaysia sejak pernyataan kemerdekaan, September 1963. Secara hukum internasional, Malaysia dapat menggunakan tindakan kedaulatan negara atas gangguan dan ancaman wilayah kedaulatan, sebagai hak membela diri (self defend right). Sultan Sulu, yang ditenggarai pemimpin masyarakat Muslim, warga negara Filipina membuktikan pihak-pihak yang terlibat persoalan Sabah, tidak memiliki jurisdiksi yang dapat berperkara di tingkat internasional. Terkecuali, jika terdapat unsur pelanggaran atau kejahatan HAM yang memungkinkan individu melakukan legal action terhadap negara. 


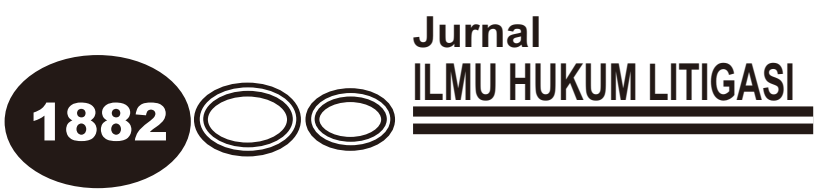

C. Konflik Bersenjata di Sabah

Meskipun secara teoritik dan asas-asas hukum internasional, status hukum Sabah sebagai Negara Bagian Malaysia telah jelas. Namun, tidaklah sama sekali dapat terbebas dari persoalan hukum yang timbul di kemudian hari. Dalam konteks hubungan baik antara negara-negara bertetangga (good neighbor relations), Malaysia, Indonesia, dan juga Filipina tampaknya memiliki kaitan historis, baik terkait batas wilayah negara dalam arti daratan dan lautan, maupun dalam arti hubungan sejarah kesultanan, kekerabatan dan hubungan tali temali keagamaan serta hak-hak masyarakat adat.

Pemerintah Malaysia dengan keturunan Sultan Sulu dan/atau keturunannya yang terlibat dalam sengketa, bukan merupakan pihak-pihak yang memiliki kesamaan status dalam hukum internasional. Konflik bersenjata hanya diakui jika pihak-pihak yang terlibat adalah negara sebagai subyek hukum. Dalam kaitannya dengan klaim atas Sabah sebagai wilayah kedaulatan Sultan Sulu, dapat mengundang penafsiran berbeda-beda. Tindakan militer kerajaan Malaysia yang berakibat tewasnya pendukung Sultan Sulu, mendapatkan pembenaran teoritik dari segi hukum internasional. Persoalannya, apakah konflik bersenjata di Sabah di dorong motif konflik wilayah perbatasan ataukah bukan?. 
Menurut Victor Prescott, suatu sengketa di wilayah perbatasan terjadi jika masuk pada empat (4) kelompok di bawah ini:

a. Positional dispute, adalah sengketa yang terjadi akibat adanya perbedaan interpretasi mengenai dokumen hukum atau adanya perubahan di lokasi yang berupa perubahan tanda-tanda fisik yang dipakasi sebagai perbatasan.

b. Territorial dispute, adalah sengketa yang terjadi ketika dua atau lebih negara mengklaim suatu wilayah yang sama sebagai wilayahnya atau bagian dari wilayahnya. Hal ini terjadi karena alasan sejarah atau kepentingan geografis.

c. Functional dispute, adalah sengketa yang terjadi adanya pengerahan orang-orang dan barang-barang, karena tiadanya penjagaan yang terlalu ketat.

d. Transboundary resource dispute, adalah sengketa yang muncul karena adanya eksploitasi sumber daya alam oleh negara lain dan merugikan negara lain di perbatasan (Wahyuni, Kartikasari dalam Ludiro, Madu dkk, 2010 : 91).

Dari keempat model sengketa tersebut, hampir sulit untuk menempatkan kasus Sabah ke dalam konflik dengan salah satu motif tersebut. Prescott juga menyebutkan, bahwa adanya pendekatan lain dalam memahami persoalan sengketa di sebuah wilayah. Hukum internasional yang biasa digunakan untuk menentukan wilayah kedaulatan, termasuk penggunaan konsep terra nullius, hanyalah berlaku bagi negara-negara Eropa pada zaman penjajahan antara abad ke-18 hingga abad 19-an. Sebelumnya, terdapat konsep hubungan hukum tentang Darul Islam, konsep kedaulatan negara- 


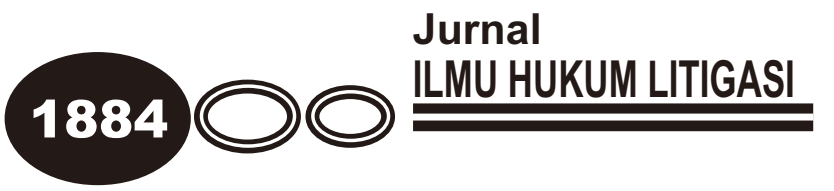

negara Islam. Kedudukan Algeria di gurun Sahara tidak dapat dikenakan status “pemilikan" atas dasar terra nullius.

Mereka memiliki hubungan hukum antara wilayah-wilayah negaranegara tetangga dengan karakter khusus yang ditandai oleh organisasi sosial politik, dan terkait persoalan kependudukan. Praktek pengadilan di Afrika, mengakui keberadaan hubungan hukum persekutuan antara Sultan Maroko dan orang-orang di gurun Sahara, yang didasarkan pada pelaksanaan pengaruh negara-negara Muslim terhadap suku-suku di Afrika. Pengadilan juga mengakui bahwa orang - orang yang masih nomaden, pada zaman penjajahan menimbulkan persoalan hubungan hukum yang khusus yang perlu menjadi bahan pertimbangan.

Kerangka teori diatas relevan untuk dipertimbangkan bahwa Sabah sebagai wilayah kedaulatan Malaysia, dapat terbebas dari klaim pemilikan wilayah Sultan Sulu. Namun, tidak menutup kemungkinan sebagian warga negara Malaysia yang tinggal di Sabah, memiliki hubungan dalam arti kekerabatan, keagamaan, dan hak-hak masyarakat hukum adat (Shaw, Malcolm, 1986 : 57). Untuk itu, perlu dijelaskan bagaimana konflik di Sabah tergolong konflik bersenjata yang dapat dianalisis melalui norma-norma hukum Humaniter dan HAM Internasional. 
Apakah konflik bersenjata yang terjadi di Sabah merupakan kategori konflik bersenjata internasional (international arm conflict) atau konflik bersenjata non-internasional (non-arm international conflict)? Di satu pihak, Sabah sebagai wilayah Negara Bagian Malaysia mengingat beberapa alasan; (1) Referendum di Sabah dan Serawak, dibawah pengawasan PBB yang hasilnya kedua tempat tersebut disetujui menjadi wilayah kedaulatan Negara Malaysia (http://en.wikipedia.org/wiki/History, http://en.wikipedia.org/wiki/Cobbold, dan http://www.freemalaysiatoday.com). (2) Status hukum Sabah hampir tidak pemah dipersoalkan secara juridis dan politis sejak deklarasi kemerdekaan tahun 1963 sampai dengan 2012. (3) Pengakuan Presiden Filipina, dalam suatu KTT ASEAN atas Sabah sebagai wilayah kedaulatan Malaysia (http://english.astroawani.com). (4) Uti posidetis juris dan effective occupation tidak meragukan keberadaan Sabah, baik sebagai wilayah bekas jajahan, yang sudah ada penghuninya, atau tidak pernah menjadi daerah kosong (terra nullius). (5) Tidak pernah terdengar atau terbukti bahwa Sultan Sulu melakukan protes terhadap Malaysia ketika Sabah dijadikan wilayah Malaysia. 


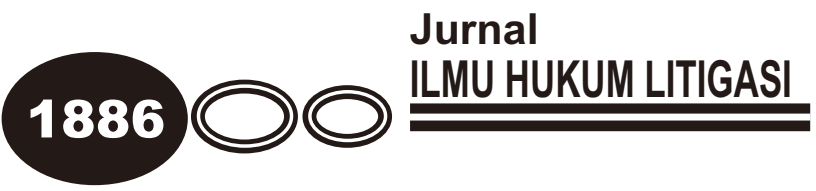

Di pihak lain, Sultan Sulu mengklaim Sabah sebagai wilayah pemilikannya. Argumentasinya adalah (1) Sultan Sulu menerima Sabah sebagai hadiah atas jasa bantuan tentara Sultan Sulu membantu Sultan Brunei dalam menumpas pemberontakan pada tahun 1658. (2) Sultan Sulu pernah menyerahkan urusan Sabah kepada Presiden Ferdinand Marcos untuk dilakukan negosiasi atas status Sabah. Namun, Ferdinand Marcos tidak berhasil melakukan perundingan. Kegagalan negosiasi ini melemahkan posisi klaim Sultan Sulu. (3) Pada masa penjajahan Inggris tahun 1878, wilayah Sabah disewakan pada British North Borneo Company dan perusahaan tersebut membayar 5.300 keping emas Meksiko, versi lainnya mengatakan sebesar US\$ 5.000 (http://www.tempo.co/read/news). (4) Kesultanan Sulu mengaku menerima uang sewa, tetapi Pemerintah Malaysia menyebutkan sebagai semacam uang pelepasan. (5) Perundingan antara MNLF (Moro National Liberation Front) dengan Pemerintah Filipina oktober 2012, melepaskan Sabah dari kepemilikan Sultan Sulu (Harian Kompas, tanggal 14 Maret 2013). Melihat argumentasi masing-masing, maka kedua belah pihak yang terlibat dalam konflik dapat tidak memiliki status hukum yang sederajat dalam hukum internasional. Di satu pihak, Malaysia sebagai subyek hukum internasional memiliki jurisdiksi di Mahkamah Internasional. Di pihak lain, 
Sultan Sulu dan pengikutnya warga negara Filipina, yang memiliki hak klaim keperdataan dan tidak dapat memperkarakan Malaysia di Mahkamah Internasional karena bukan subyek hukum internasional. Karena itu, tidaklah mudah untuk menempatkan konflik bersenjata dalam dua kategori diatas. Bahwa kedua belah pihak aparat polisi Diraja Malaysia dengan pengikut Sultan Sulu yang tinggal di Mindanau telah terlibat baku tembak tidak terbantahkan. Persoalannya, apakah konflik bersenjata tersebut bersifat internasional atau non-internasional? Dari perspektif hukum internasional, tampaknya konflik bersenjata di Sabah tidak dapat dimasukkan ke dalam dua jenis konflik bersenjata yang jamak dikedepankan.

Pertama, konflik bersenjata secara internasional (international arm conflict) mengharuskan adanya persyaratan, suatu persengketaan yang melibatkan dua negara atau lebih, ditandai secara formal (suatu pernyataan atau dinyatakan secara terbuka), atau situasi yang menyebabkan diterapkan penggunaan kekerasan, dengan alasan-alasan rasional untuk mencapai tujuan, hak membela diri (self defend rights), mematuhi ketentuan hukum perang, melibatkan aktor-aktor combatant, dengan berbagai perlengkapan peperangan, baik tradisional ataupun modern yang secara eksklusif menimbulkan berbagai akibat dan penderitaan. Hal ini diatur dalam Pasal 3 ayat (1) Konvensi Jenewa 


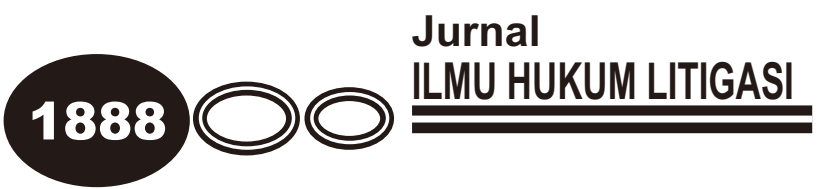

1949 tentang Perbaikan Keadaan Anggota Angkatan Perang Yang Luka dan Sakit di Medan Pertempuran Darat.

Kedua, konflik bersenjata non-international (non-international armed conflict), suatu persengketaan bersenjata, dilakukan oleh suatu pemerintahan, menggunakan kelompok bersenjata dengan kelompok sipil bersenjata insurgensi, belligerent, atau kelompok bersenjata lainnya atas motif hak untuk mendirikan pemerintahan sendiri (self determination rights) atau sejenis otonomi khusus, dengan motif lainnya, dapat memperoleh hak-hak sosial, ekonomi dan budaya. Dalam prakteknya konflik bersenjata non-internasional diatur dalam Pasal 1 ayat (1) Protokol Tambahan Tahun 1977 dan Pasal 1 ayat (2) (Direktorat Jenderal Administrasi Hukum Umum, 2003).

Diakui bahwa konflik bersenjata di Sabah tidak mudah dikelompokkan pada dua jenis pertikaian yang diakui internasional, pemberlakuan $\mathrm{HHI}$ khususnya Hukum Jenewa 1949 dan Protokol II 1977 tidak dapat dihindarkan. Namun, terdapat beberapa petunjuk relevan dapat digunakan menguji kasus konflik bersenjata di Sabah Malaysia.

Pertama, 9 Februari 2013, utusan Sultan Sulu Gamalul Kiram III yang dipimpin Agbimudin Kiram, adik bungsunya berangkat ke Sabah, yang juga disertai ratusan pengikutnya. Sebagian mereka membawa senjata dan langsung 
mendarat serta melakukan aksinya di kawasan Lahad Datu (Harian Kompas, tanggal 6 Maret 2013). Setidaknya, kelompok Sultan Sulu yang bersenjata sebagai combatant yang memiliki komando, dan juga diberlakukan prinsip distiction atau pembeda (Arlina, Permanasari, et.al (ed), 1999, 75-77). Situasi penyusupan dilakukan pengikut Sultan Sulu, membuat Pemerintah Malaysia melakukan tindakan kedaulatan melalui aparat militer atau Polisi Diraja Malaysia. Pada tanggal 2 Maret 2013 terjadi baku tembak antara pengikut Sultan Sulu dengan petugas keamanan Malaysia. Baku tembak yang dilakukan kedua belah pihak menunjukkan adanya unsur combatant, yaitu disatu pihak pasukan pendukung Sultan Sulu bersenjata dan dipihak lain aparat Malaysia.

Kedua, sejak tanggal 2 Maret sampai dengan tanggal 5 Maret 2013, telah terjadi serangan senjata yang mengakibatkan sedikitnya 52 pengikut Sultan Sulu tewas. Jumlah korban tewas meningkat salah satu akibatnya karena Pemerintah Malaysia telah memperlengkapi diri dengan pasukan tempur dengan tujuh batalyon (7000 personil), kendaraan lapis baja, serta pesawat tempur F-18 dan Hawk (Hari Jawa Pos, tanggal 8 Maret 2013). Namun, pihak lain mencatat jumlah yang tewas adalah 63 orang, dan tidak kurang dari 8 anggota aparat keamanan Malaysia terbunuh. Tidak sedikit dijumpai korban 


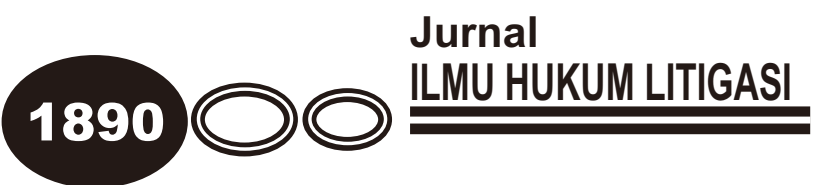

luka-luka. Pemerintah Malaysia juga telah menangkap 79 pengikut Sultan Sulu yang dianggap menginvasi Sabah (Harian Kompas, tanggal 10 Maret dan 14 Maret 2013). Karena telah terjadi korban, maka timbul pertanggung jawaban hukum. Pihak mana yang patut dipersalahkan menurut HHI. Akibat korban tersebut sejatinya membuka pihak-pihak luar, Organisasi Palang Merah Internasional dan wartawan untuk meliputnya secara adil dan proporsional. Kekhususan berperang secara adil jus in bellum, mengikat keterbukaan.

Ketiga, terdapat wilayah sebagai ajang pertempuran yaitu Lahad Datu, Seumpurna, dan Kunah. Ketiga tempat tersebut, umumnya diduduki oleh orang-orang yang berkewarganegaraan Malaysia. Ketiga daerah tersebut berada di wilayah negara bagian Malaysia, yang dalam ikatan sejarah (historical connection) sebagai hadiah dari Sultan Brunei. Sultan Sulu menguasai wilayah kepulauan yang sangat luas dan kaya dengan berbagai kekayaan alam. Daerah ini, dipandang tiga daerah sebagai pusat konsentrasi sipil bersenjata Sultan Sulu. Diperkirakan, adik bungsu Sultan Jamaludin Kiram III yaitu Raja Muda Agbimuddin Kiram telah tewas dalam konflik tersebut (http://internasional.kompas.com). 
Keempat, motif yang timbul dibalik penggunaan senjata, oleh pengikut

Sultan Sulu Jamalul Kiram III, adalah ketidakpuasan atau perlakuan tidak sebanding. Salah satu faktanya yaitu, Pemerintah Filipina telah gagal memfasilitasi harapan Sultan Sulu ketika persoalan klaim wilayah Sabah diserahkan oleh Sultan Muhammad Esmail Kiram yang bertemu dengan Wakil Presiden sekaligus Menteri Luar Negeri Emanuel Pealez (Harian Kompas, tanggal 6 Maret 2013). Dalam informasi lain, tahun 1962, Kesultanan Sulu memberikan mandat kepada Presiden Filipina Diosdado Macapagal untuk melakukan negosiasi soal Sabah. Setiap tahun, Kedubes Malaysia di Manila mengirim $77.442,36$ peso, atau 1.500 dolar AS, atau Rp 14.250.000 (jika kurs 1 dolar $=\mathrm{Rp} 9.500$ ), sama dengan gaji pegawai negeri rendahan di Kuala Lumpur. Luas Sabah adalah 73.711 kilometer persegi. Jadi, harga sewa Sabah per kilometer persegi yang dibayarkan Malaysia ke keluarga Sultan Sabah adalah 0,02 dolar AS, atau Rp 193 rupiah. Sedangkan, gross domestic product Malaysia di Sabah diperkirakan mencapai 100 miliar dolar AS per tahun (http://www.republika.co.id).

Kelima, pihak Pemerintah Malaysia menolak usulan gencatan senjata yang diajukan beberapa pihak, khususnya negosiator wakil Pemerintah Filipina. Pemerintah Malaysia sendiri bukan saja tidak merespon, tetapi juga menolak 


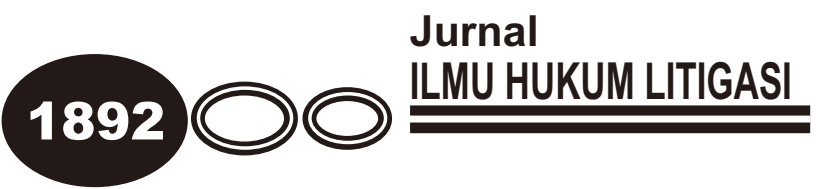

negosiator Filipina untuk masuk ke wilayah konflik. Usulan dari Sekjen PBB agar perundingan lebih diutamakan, tampaknya tidak ada tanggapan. Sultan Brunei Darussalam, sebagai Ketua ASEAN, juga tidak pro-aktif untuk ambil bagian dalam penyelesaian persenjataan tersebut. Sikap apatis tersebut boleh jadi timbul karena kesepuluh negara-negara anggota ASEAN memegang prinsip non-intervensi. Tindakan Malaysia secara militer atas pendukung Sultan Sulu tersebut justru menempatkan Pemerintah Filipina dalam posisi dilema. Jika fakta penyerbuan oleh pendukung Sultan Sulu ke Sabah benar adanya, maka Pemerintah Malaysia dapat dengan mudah menuding Pemerintah Filipina tidak melaksanakan kewajiban negara secara benar. Menurut Montevideo Convention 1933, negara berkewajiban untuk mencegah warga negara melakukan tindakan kedaulatan di negara lain (Starke, J. G., 2004). Sebaliknya, tindakan militer Malaysia yang melakukan pertahanan yang terkesan membabi buta, juga berpeluang dipersoalkan dari segi Hukum Humaniter Internasional. 
D. Pertanggung jawaban Hukum

Pertanggungjawaban hukum (legal responsibility) dalam hukum internasional, dapat dibebankan kepada pihak-pihak ketika adanya perbuatan salah satu pihak (negara) karena tidak mematuhi kewajiban-kewajiban, bersumber pada perjanjian intemasional atau karena perbuatan tersebut bertentangan dengan larangan - larangan yang tertuang dalam beberapa peraturan hukum internasional dan sumber hukum internasional lainnya (Jawahir dan Pranoto, 2006 : 193). Terkait dengan kasus konflik bersenjata di Sabah, pertanggung jawaban hukum lebih difokuskan pada persoalan publik, tanpa menutup kemungkinan bagi penyelesaian non-publik.

Pertama, pertanggungjawaban publik bersifat internasional yaitu pengujian fakta pertikaian senjata antar pihak Pemerintah Malaysia dengan kelompok sipil bersenjata pendukung Sultan Sulu. Ditingkat pengadilan internasional, Pemerintah Malaysia dapat dituntut pertanggungjawaban hukum internasional. Kebijakan militer Malaysia tidak mengindahkan prinsip-prinsip dalam konflik bersenjata yaitu prinsip proporsionalitas, prinsip fairness, dan prinsip kepantasan. Pendukung Sultan Sulu sekitar 200-300 orang yang sebagian bersenjata menyusup ke Sabah, berkesesuaian dengan kewajiban yang diharuskan oleh Hukum Jenewa dan/atau Protokol Tambahan II 1977. 


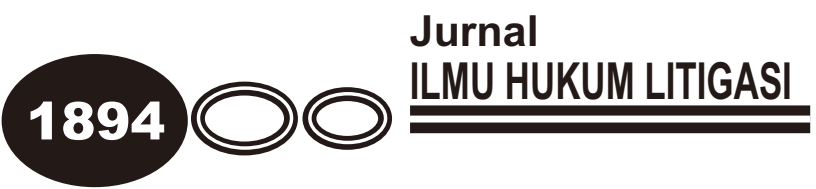

Khususnya, terkait dengan kondisi sipil bersenjata. Jika prinsip proporsionalitas dan keadilan secara faktual dan juridis terabaikan oleh Pimpinan militer atau Komando militer Malaysia, maka Perdana Menteri Malaysia wajib melakukan investigasi atau membentuk Tim pencari fakta untuk melakukan proses hukum yang fair . Prinsip ini tercantum dalam Pasal 35 ayat (2) Protokol Tambahan I: "It is prohibited to employ weapons, projectiles and material and methods of warfare of a nature to cause superfluous injury or unnecessary suffering".

Pertanggungjawaban hukum secara internasional dapat dibebankan pada militer Malaysia atau polisi Malaysia. Pertama, Sabah adalah tempat kejadian persengketaan senjata, merupakan locus delicti yang menempatkan Pemerintah Malaysia memiliki jurisdiksi atas wilayahnya. Pemerintah Malaysia yang tampak kurang antisipatif, atau diduga lalai untuk membiarkan tragedi berdarah ini terjadi, dapat digunakan sebagai peluang hukum oleh masyarakat intemasional, khususnya Komisi HAM Internasional untuk menuntut pertanggungjawaban pada Pemerintah Malaysia. Pertanggungjawaban dapat dibebankan karena pembiaran, atau tidak melakukan tindakan yang seharusnya. Pelanggaran HAM-nya, selain dijumpai ada perencanaan, perbuatan (commission), juga diduga ada pembiaran (ommission) (Robertson, Geoffrey, 2000). 
Kedua, pertanggungjawaban hukum dapat dibebankan pada Militer atau aparat Polisi Malaysia karena pelanggaran atas prinsip proporsionalitas atau keseimbangan. Fakta menunjukan adanya ketidakseimbangan karena pendukung Sultan Sulu sebanyak 200-300 orang melawan 7000 militer dengan perlengkapan militer darat, laut dan udara yang cukup masife dari pihak Malaysia. Bukti-bukti tersebut dapat dikualifikasikan ke dalam pelanggaran asas proporsionalitas didukung oleh jumlah korban 67 orang tewas dari pengikut Sultan Sulu, dan sekitar 7 orang dari Kepolisian Diraja Malaysia.

Ketiga, tidak pernah terdengar sebelumnya, Pemerintah Malaysia melakukan pendekatan persuasif atas kehadiran pendukung Sultan Sulu yang memaksa masuk wilayah kedaulatan Malaysia. Dipandang dari segi hukum keimigrasian, penyusup Sultan Sulu memasuki wilayah Sabah secara tidak sah, semestinya merupakan tugas yang dibebankan pada penjagaan Angkatan Laut dan keimigrasian untuk menghalau mereka. Karena itu, peristiwa yang berakhir dengan konflik bersenjata memperlihatkan tindakan Pemerintah Malaysia berlebihan (exessive treatment) (http://www.crimesofwar.org). Kondisi tersebut dapat diduga tidak mematuhi Pasal 1 ayat (3) Piagam PBB. 


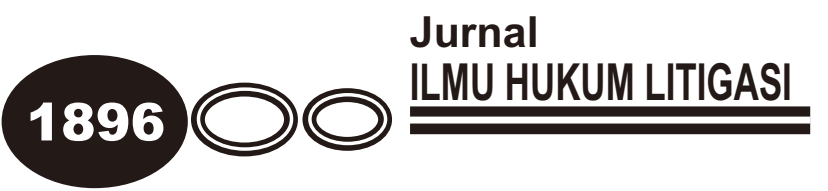

Kedua, pertanggungjawaban hukum nasional juga dapat dilakukan oleh Pemerintah Malaysia terhadap 76 tahanan pendukung Sultan Sulu. Pemerintah Malaysia dapat membawanya ke pengadilan pidana nasional dengan berlapis ancaman tuntutan berlapis. Pertama, 76 orang pendukung Sultan Sulu diduga melakukan pelanggaran keimigrasian dan membawa senjata api, pelanggaran atas Undang-Undang Keamanan Nasional (internal security act), dan Undang-Undang Terorisme (http://en.wikipedia.org/wiki/Internal). Malaysia memiliki jurisdiksi yang kuat untuk mempertanggungjawabkan hukum pada pendukung Sultan Sulu di tingkat pengadilan Negara Bagian Sabah. Sebaliknya, Pemerintah Filipina memiliki hak hukum atas dasar protective principle atau national active untuk memberikan pembelaan, atau menggunakan pendekatan diplomasi. Termasuk, kemungkinan solusi melalui penggunaan perjanjian ekstradisi atau perjanjian tukar menukar penjahat yang ada di Malaysia dengan Filipina.

Tidak menutup kemungkinan bagi Sultan Sulu jika memang memiliki bukti-bukti yang didasarkan pada perjanjian sewa dengan British North Borneo Company. Termasuk adanya pengakuan status uang yang diberikan oleh Pemerintah Malaysia kepada keturunan Sultan Sulu hingga saat ini. Di luar pertanggung jawaban pidana, tersisa persoalan keperdataan yang melihat pada 
hak-hak individual sebagai orang asing yang juga wajib dilindungi oleh Malaysia. Terbukanya tuntutan individual tersebut didasarkan selain pada hakhak sosial, ekonomi, dan politik (international convention social, economic and political rights 1966). Selain itu, hak individual untuk diperlakukan secara berkeadilan oleh negara manapun, telah menjadi keniscayaan dan hakikat hukum internasional yang berfungsi bagi negara-negara, akan tetapi perlindungan hak-hak individu yang tinggal di muka bumi ini. Petter Singer, penulis buku One Earth (Singer, Peter, 2012 : 166), menyimpulkan bahwa fungsi hukum internasional yang menyediakan akses keadilan bagi setiap individu, memiliki hak klaim yang sama atas perlakuan yang adil. Karena itu, posisi individu sebagai subyek hukum internasional telah hadir dan diterima oleh sebagian masyarakat internasional, didasarkan pada realitas keadilan global (global justice), juga dukungan teoritis dan keadilan kosmopolit (cosmopolitant justice) (Twining, William, $2000: 258$ ). 


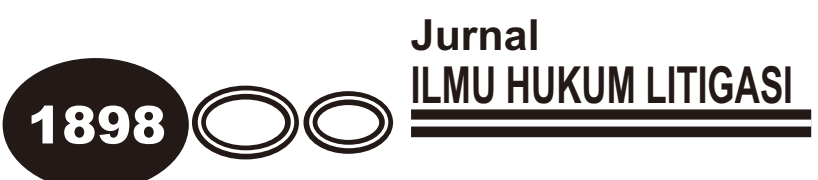

\section{SIMPULAN DAN SARAN}

A. Simpulan

Pembahasan di atas telah membawa kita pada suatu simpulan sebagai berikut:

1. Suatu negara dalam hukum internasional menguasai atau memiliki wilayah kedaulatan bersumber pada teori dan praktek yang beraneka ragam. Di satu pihak, klaim wilayah kedaulatan negara secara utuh dan memiliki status hukum yang jelas dan pasti dapat timbul ketika konsep uti posidetis juris dan effective occupation menjadi dasar hukum utama (primary source of law). Di pihak lain, penerapan asas tersebut tidak secara otomatis dapat menjamin kepastian hukum terhadap batas-batas wilayah antara kedua negara bertetangga lebih rinci, atau status sebagai wilayah yang masih berada dalam status ikatan perjanjian. Itulah sebabnya, Malcolm Shaw dan Victor Prescott mendorong negara-negara untuk bekerjasama menentukan batas wilayah masing-masing melalui metode allocation, demarcation, delimitation, dan joint border committee. 
2. Status Sabah sebagai Negara Bagian Malaysia sangat lejitimit dan tidak terlihat celah yang memungkinkan pihak ketiga, termasuk Sultan Sulu Jamaluddin Kiram III menduduki wilayah tersebut. Kepastian hukum sebagai wilayah kedaulatan Malaysia, didukung oleh argumentasi juridis dan non-juridis. Secara juridis formal status Sabah menjadi kuat mengingat proses transformasi kekuasaan dari Penjajahan Inggris ke Malaysia menjadi negara merdeka sejak September 1963, telah diakui secara sah oleh PBB. Hak kedaulatan eksklusif Pemerintah Malaysia terhadap negara-negara bagiannya hingga berlangsung selama 50 (lima puluh) tahunan tidak pernah menimbulkan persoalan, baik secara hukum maupun politis. Sedangkan dari pendekatan non-hukum, hubungan kesejarahan, kekerabatan, dan keagamaan yang dimiliki Sultan Jamaluddin Kiram III, yang bersifat keperdataan memungkinkan adanya hak keuntungan bersifat keperdataan. Namun, hak tersebut tidak dapat menghalangi atau mengecualikan Sabah dari proses suksesi lahirnya Negara Malaysia yang merdeka dari Penjajahan Inggris.

3. Konflik bersenjata di wilayah Sabah telah terjadi dengan melibatkan kelompok penyusup bersenjata mewakili kepentingan politik Sultan Sulu dengan aparat keamanan (militer dan polisi) Malaysia, mengacu pada 


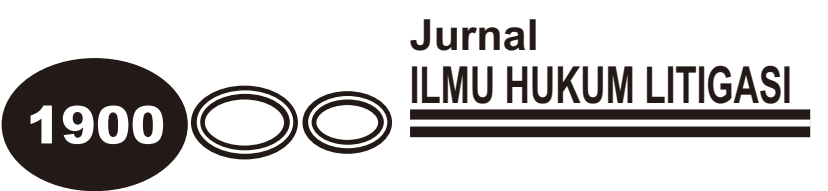

HHI atas dasar Geneva Convention 1949 dan Protokol Tambahan II 1977. Penggunaan HHI tersebut menjadi sangat penting bukan sekedar untuk menentukan formalitas terjadinya permusuhan, akan tetapi karena secara faktual telah timbul korban-korban tewas dan luka-luka, serta adanya penahanan terhadap 76 penyusup pendukung Sultan Sulu di Malaysia. Diakui bahwa konflik bersenjata di Sabah tidak mudah dikelompokan pada konflik bersenjata internasional, dan juga konflik bersenjata non-intemasional. Namun, kedua belah pihak dapat dimintai pertanggungjawaban hukum sesuai hukum internasional dan juga hukum nasional. Di satu pihak, kebijakan militer Pemerintah Malaysia yang telah menewaskan 67 orang pendukung Sultan Sulu sebagai dugaan adanya pelanggaran asas proporsionalitas dan keadilan. Penggunaan 7000 militer dan fasilitas persenjataan lainnya memperlihatkan bukti yang relevan bila dibandingkan dengan jumlah penyusup sah sebanyak 200-300 orang, dengan sebagian peralatan senjata yang mereka gunakan. Meski tidak mudah direalisasikan, secara teoritis dan juridis, kasus tersebut membuka peluang untuk diselesaikan melalui pengadilan internasional dan nasional. Di pihak lain, Pemerintah Malaysia memiliki jurisdiksi untuk membawa 76 orang yang tertangkap ke pengadilan nasional Malaysia. Tuduhan 
yang dapat disangkakan adalah segerombolan penyusup Sultan Sulu telah melakukan pelanggaran pendudukan yang tidak sah. Pelanggaran yang harus dibuktikan tidak saja dari segi hukum keimigrasian, karena mereka telah memasuki wilayah tanpa izin atau dokumen hukum (illegal tresspases). Tetapi juga dapat digunakan Pasal-pasal terkait UndangUndang Terorisme dan Undang-Undang Keamanan Dalam Negeri (internal security act). Jika proses pengadilan tersebut dapat diselenggarakan atas dasar pentingnya penegakan hukum dan keadilan, maka hak gugat keperdataan bagi Sultan

Sulu atas nama subyek hukum non-negara, bukan hal yang mustahil untuk dikedepankan. 


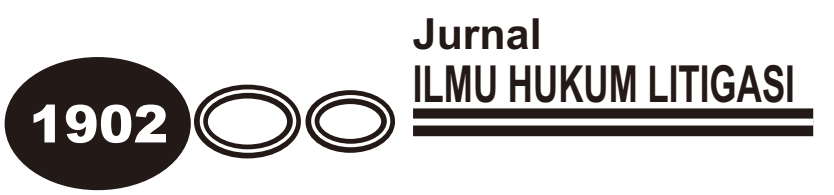

B. Saran

1. Sebagai telah disampaikan dalam kesimpulan bahwa kontak senjata antara pendukung Sultan Sulu dengan polisi dan tentara tidak termasuk dalam konflik bersenjata sebagaimana diatur dalam Konvensi Genewa 1948 melainkan lebih sebagai tindakan bela diri dilakukan oleh aparat keamanan atas dasar menjaga kedaulatan. Namun tidaklah berarti bahwa Sultan Sulu tidak memiliki hak klaim atas sebagian tanah di Negara Sabah. Karena klaim kepemilikan lebih merupakan isu hukum keperdataan, yang mustahil dapat diselesaikan di Mahkamah Internasional, tidak menutup kemungkinan celah untuk menggugat status uang sewa yang selama ini pernah diterima keluarga Sultan Sulu.

2. Dalam rangka mempersiapkan gugatan atas hak dan status tanah, pihak Sulatan Sulu memerlukan kerja keras untuk mengumpulkan bukti-bukti formil, dan saksi-saksi untuk memperkuat argumentasi dalam surat gugatan.

3. Perlu dipertimbangkan adanya penggunaan diplomasi lokal, people to the people, antara keluarga Sultan Sabah dengan Sultan Sulu yang diduga memiliki darah biru Melayu, mengingat pendekatan hukum sangat kecil kemungkinan untuk berhasil. 


\section{DAFTAR PUSTAKA}

Arlina Permanasari, et.al (ed), 1999, Pengantar Hukum Humaniter, Jakarta, International Committee of The Red Cross.

Direktorat Jenderal Administrasi Hukum Umum, Departemen Kehakiman dan Hak Asasi Manusia Republik Indonesia, 2003, Protokol Tambahan Pada Konvensi-konvensi Jenewa 12 Agustus 1949 Dan Yang Berhubungan Dengan Perlindungan Korban-korban Pertikaian-pertikaian Bersenjata Internasional (Protokol I) Dan Bukan Internasional (Protokol II), Jakarta.

Dixon, Martin dan Robert McCorquodale, 2003, Cases and Materials on International Law, New York, Oxford University Press.

Fleck, Dieter (ed), 1995, The Handbook of Humanitarian Law in Armed Conflict, Oxford England, Oxford University Press.

Jawahir Thontowi dan Pranoto Iskandar, 2006, Hukum Internasional Kontemporer, Bandung, Refika Aditama.

Ludiro Madu, et.al, 2010, Mengelola Perbatasan Indonesia Di Dunia Tanpa Batas: Isu, Permasalahan dan Pilihan Kebijakan, Yogyakarta, Graha Ilmu.

O'Brian, John, 2001, International Law, Sydney-London, Cavendish Publishing Limited. 


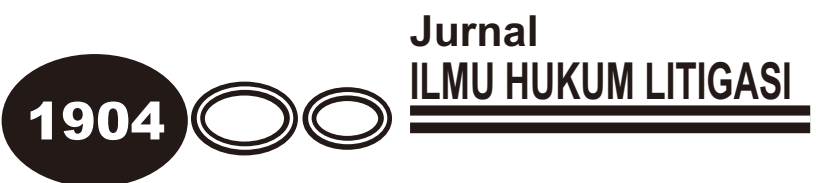

Prescott, Victor dan Gillian D. Triggs, 2008, International Frontiers and Boundaries:

Law, Politics, and Geography, Leiden, Martinus Nijhoff Publisher.

Robertson, Geoffrey, 2000, Kejahatan Terhadap Kemanusiaan, Perjuangan Untuk Mewujudkan Keadilan Global (terj), Penguin Book.

Shaw, Malcolm, 1986, Title to Territory in Africa: International Legal Issues, Oxford, Clarendon Press.

Singer, Peter, 2012, Satu Bumi. Etika Bagi Era Globalisasi (terj), New HavenLondon, Yale University Press.

Starke, ]. G., Introduction to International Law, Sydney, Butterworth. , 2004, Pengantar Hukum Internasional, Jakarta, Sinar Grafika.

Twining, William, 2000, Globalization and Legal Theory, London-Edinburgh-Dublin, Butterworths Publishers.

Wahyuni Kartikasari, 2010, Mengurai Pengelolaan Perbatasan di Wilayah-wilayah Perbatasan Indonesia, dalam Ludiro Madu dkk (editor), Mengelola Perbatasan Indonesia di Dunia Tanpa Batas: Isu Permasalahan dan Pilihan Kebijakan, Yogyakarta, Graha IImu. 


\section{JURNAL}

Jawahir Thontowi, 2012, Bilateral Cooperation Between Government of Indonesia and Malaysia, Jurnal Unisia.

\section{MEDIA MASSA}

Yordan Gunawan, Kesultanan Sulu dan Sabah, Kedaulatan Rakyat, 10 Maret 2013

Sulit Bedakan Warga dan Penyusup Sulu, Jawa Pos, Jumat 8 Maret 2013.

Kesultanan Sulu: Lika-liku Sejarah Klaim Sabah, Kompas, Rabu 6 Maret 2013.

Opini Kompas, Sabtu 10 Maret dan Kamis 14 Maret 2013

MS. Noor, Insiden Sabah dan Klaim Batas Sejarah, Kompas, 14 Maret 2013

Ple Priatna, Sabah, Konflik, dan Belenggu ASEAN, Kompas, Sabtu 16 Maret 2013

\section{WEBSITE}

http://en.wikipedia.org/wiki/Cobbold Commission,

http://en.wikipedia.org/wiki/History of Sabah

$\begin{array}{llll}\text { Internal } & \text { Security } & \text { Act } & \text { Malaysia, diakses }\end{array}$ http://en.wikipedia.org/wiki/Internal_Security_Act_(Malaysia) http://en.wikipedia.org/wiki/Member states of the Commonwealth of Nations 


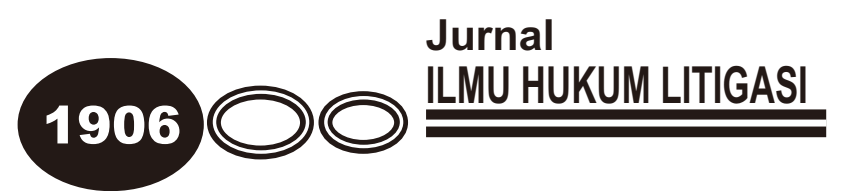

http://en.wikipedia.org/wiki/United Nations Security Council Resolution 1246

http://english.astroawani.com/news/show/why-sabah-belongs-to-malaysia-9355

http://id.wikipedia.org/wiki/Daftar negara bagian_di Malaysia

http://id.wikisource.org/wiki/Piagam Perserikatan Bangsa-Bangsa

Polisi Malaysia Temukan Jasad Adik Sultan Sulu, diakses dari http://internasional.kompas.com/read/2013/03/12/15530547/Polisi.Mala ysia.Temukan.Jasad.Adik.Sultan.Sulu

http://www.bulawayo 1872.com/history/lobengula.htm

Principle of Proportionality, diakses dari http://www.crimesofwar.org/a-zguide/proportionally-principle-of/

http://www.freemalaysiatoday.com/category/nation/2013/03/08/there-was-nosabah-referendum/

Brad Simpson, Indonesia's 1969 Takeover of West Papua Not by "Free Choice", The National Security Archive, 2004, diakses dari http://www.gwu.edu/ nsarchiv/NSAEBB/NSAEBB128/

Kontroversi Malaysia Soal Sabah, diakses dari http://www.republika.co.id/berita/internasional/asean/13/03/11/mjhcnokontroversi-malaysia-soal-sabah 
http://www.tempo.co/read/news/2013/03/05/115465135/Perjalanan-Pulang-

Keluarga-Sultan-Sulu-ke-Sabah.

\section{PERATURAN PERUNDANGAN}

Konvensi Jenewa 1949 Tentang Perbaikan Keadaan Anggota Angkatan Perang Yang Luka dan Sakit di Medan Pertempuran Darat.

Protokol Tambahan Pada Konvensi-konvensi Jenewa 12 Agustus 1949 dan yang Berhubungan dengan Perlindungan Korban-korban Pertikaian-pertikaian Bersenjata Internasional (Protokol I) dan Bukan Internasional (Protokol II). 